\title{
Miejsce przewozów w działalności przedsiębiorstw na przykładzie firmy ABC
}

\author{
Tetiana Kulish*
}

\begin{abstract}
Streszczenie: Podczas analizy łańcucha dostaw można zauważyć, że nawet najkorzystniejsza oferta cenowa obejmuje koszty transportu. Artykuł ma na celu zbadanie zależności kosztów transportu od ostatecznych cen produktów i zainteresowania klientów produktami końcowymi. W artykule zaprezentowano powiązanie pomiędzy elementami przepływów logistycznych i zespołem ludzi wykonujących i realizujących zamówienie jako całość. Również rozpatrzono temat efektywności różnych rodzajów transportu, optymalizacji transportu i zmniejszenia kosztów dostaw. Była prowadzona ocena różnych rodzajów transportu dla różnych czynników go kształtujących. Został poruszony temat poprawy jakości usług dzięki wprowadzeniu systemu zarządzania zgodnie z międzynarodowymi standardami (w tym ISO 28000).
\end{abstract}

Słowa kluczowe: transport, koszty logistyki, środki transportu, jakość usług.

\section{Wstęp}

Transport odgrywa bardzo istotną rolę w życiu każdego przedsiębiorstwa, firmy i człowieka. Od działalności transportu zależy rozwój i funkcjonowanie przedsiębiorstw, przemysłu, rolnictwa, logistyki i handlu. Transport ma wielkie znaczenie w zagranicznych stosunkach gospodarczych, w obronie kraju, w rozwoju nowych regionów gospodarczych.

Transport to bardzo ważny element końcowego kosztu produktu, więc koniecznym jest odpowiedni wybór optymalnego systemu logistycznego, który przyniesie zadowolenie klienta i będzie korzystny dla wszystkich stron transakcji. Ważną kwestią jest, aby połączyć nie jeden, a kilka rodzajów transportu w celu optymalizacji kosztów transportu.

* Uniwersytet Łódzki, Wydział Zarządzania. 


\section{Opis firmy ABC i jej działalności}

Firma ABC została zarejestrowana w Sofii w Bułgarii. Jej działania można podzielić na dwa obszary. Pierwszym z nich jest działalność naukowo-techniczna związana z projektami środowiskowymi, zmniejszeniem wpływu działalności człowieka na środowisko, poprawą efektywności energetycznej przedsiębiorstwa, recyklingiem i przetwarzaniem odpadów oraz ścieków komunalnych, produkcją żywności. Drugi obszar jest ściśle związany z pierwszym, choć działa niezależnie. Zajmuje się on zapewnieniem transportu towarów na potrzeby spółki i dla klienta, podczas realizacji umów kupna-sprzedaży.

Firma prowadzi swoją działalność nie tylko na terenie Unii Europejskiej; umowami handlowymi jest związana z republikami WNP (Ukraina, Mołdawia, Białoruś, Gruzja), a także z krajami azjatyckimi (Indie, Chiny). Kolejnym kontynentem, z którym kooperuje analizowana firma jest Afryka (w 2016 r.).

Doprowadziło to do konieczności rozszerzenia działalności firmy i oferty. Podstawowe prace zostały rozszerzone o organizowanie transportu dla następujących towarów:

- spożywczych: zboża (kukurydza, pszenica, groch), oleje roślinne (słonecznikowy, rzepakowy), ziemniaki;

- konstrukcji metalowych;

- wyrobów z drewna (palety, pellety, deski).

\section{Logistyka przepływu towarów firmy $A B C$}

Na podstawie specyfiki firmy oraz różnorodności towarów i usług znaczną część operacji logistycznych w przepływie dóbr materialnych prowadzi się za pomocą różnych form transportu, wśród których znajdują się transport drogowy, morski i lotniczy.

Transport stanowi związek między tymi elementami przepływów logistycznych i zespołów ludzi wykonujących zamówienie jako całość. Od prac działu logistyki i efektywności logistyki transportu zależy przepływ towarów, materiałów i komponentów do określonego umową miejsca i wyboru najlepszej drogi. Jednocześnie w trakcie optymalizacji transportu należy brać pod uwagę nie tylko jego koszty, ale również czas, w którym towary znajdują się w tranzycie, oraz, jeśli to konieczne, to także specyficzne warunki transportu (temperatura, wilgotność, zapewnienie bezpieczeństwa). Koszty transportu wpływają na koszt towarów oprócz tradycyjnych kosztów tworzenia produktu, które obejmują koszty produkcji, koszty do przeprowadzenia wszystkich prac od momentu zakupu materiałów do dotarcia do klienta. 
Dużą część kosztów stanowią dopłaty do każdego połączenia w łańcuchu: dostawca-klient. Doświadczenia firmy ABC pokazują, że przepływ strumienia materiału od surowca do produktów dostarczonych do klienta mogą wynieść do 50\% końcowego kosztu produktu.

Na podstawie powyższych ustaleń wynika, że kierownictwo powinno ustalić następujące cele do działu transportowo-logistycznego:

- tworzenie systemów transportowych, zamiast pojedynczych działań, w tym tworzenie korytarzy transportowych i sieci transportowych;

- zapewnienie jednolitości technologicznego procesu transportu i składowania;

- wspólne planowanie procesu transportu z hurtowni i jednostek produkcyjnych z podwykonawcami;

- określenie racjonalnej trasy;

- wybór typu i rodzaju środka transportu.

Rezultatem tego podejścia jest wysokie prawdopodobieństwo realizacji „siedmiu zasad logistyki":

- właściwy towar;

- właściwemu klientowi;

- we właściwej ilości;

- we właściwym czasie;

- we właściwym stanie;

- we właściwym miejscu;

- po właściwych (optymalnych cenach) kosztach¹.

Można stwierdzić, że logistyka transportu odgrywa bardzo ważną rolę w klasyfikacji przepływów materialnych:

- przechowywanie i pakowanie gotowych do wysyłki towarów i komponentów;

- transport wyrobów gotowych do klienta.

Firma ma jasno określone zasady transportu (wewnętrznego i zewnętrznego). Wewnętrzny transport obejmuje procedury transportowe $\mathrm{w}$ magazynach. Do transportu zewnętrznego należą procesy transportowania do konsumenta i transport między różnymi podwykonawcami. Wymienione rodzaje transportu stosowane są kompleksowo w zarządzaniu procesami logistycznymi. Celem logistyki firmy jest realizacja skomplikowanych zadań związanych z ruchem pojazdów ciężarowych ogólnego zastosowania, wspólnego planowania transportu, magazynowania i procesu produkcji, zapewniających jednolitość technologiczną w ramach realizowanego kontraktu. Każda realizacja zamówienia jest weryfikowana z punktu widzenia jego optymalizacji pod względem:

- kosztów komponentów i materiałów;

- kosztów podwykonawców (projektantów, zakładów produkcyjnych etc.);

- kosztów transportu do miejsca montażu;

1 J. J. Coyle, E. J. Bardi, J. C. Langrey Jr., Zarzq̨dzanie logistyczne, PWE, Warszawa 2002, s. 52. 
- kosztów logistyki magazynowej (opakowanie, przepakowania etc.);

- kosztów transportu do klienta.

Przykładowo - firma dostała następujące zlecenie: klient zamówił pellet A1+ z drewna iglastego z warunkiem przesyłki do Austrii. Koszt transportu przedstawiono $\mathrm{w}$ tabeli 1.

Tabela 1. Koszt transportu pelletów $w^{2} \mathrm{w}$ przedsiębiorstwie (stan na 31.07.2016)

\begin{tabular}{|c|c|c|c|c|c|}
\hline \multirow[t]{2}{*}{ Kraj pochodzenia } & \multirow{2}{*}{$\begin{array}{c}\text { Cena, } \\
\text { EUR/tonę }\end{array}$} & \multirow{2}{*}{$\begin{array}{c}\text { Odle- } \\
\text { gtość od } \\
\text { dostawcy } \\
\text { do klienta, } \\
\text { km }\end{array}$} & \multicolumn{3}{|c|}{$\begin{array}{c}\text { Koszt produktu, włączając przewóz } \\
\text { (za tonę), ze względu na rodzaj } \\
\text { transportu, EUR/tonę }\end{array}$} \\
\hline & & & $\begin{array}{l}\text { samocho- } \\
\text { dowy }\end{array}$ & kolejowy & wodny \\
\hline Butgaria (Błagojewgrad) & 75 & 1090 & $\begin{array}{c}211,25 \\
(136,25)\end{array}$ & $\begin{array}{l}132,22 \\
(57,22)\end{array}$ & $\begin{array}{l}156,75 \\
(81,75)\end{array}$ \\
\hline Rosja (Perm) & 55 & 3385 & $\begin{array}{c}478,13 \\
(423,13)\end{array}$ & $\begin{array}{c}232,71 \\
(177,71)\end{array}$ & $\begin{array}{c}266,56 \\
(211,56)\end{array}$ \\
\hline Ukraina (Mukaczewo) & 70 & 615 & $\begin{array}{l}146,88 \\
(76,88)\end{array}$ & $\begin{array}{l}102,29 \\
(32,29)\end{array}$ & Nie ma \\
\hline $\begin{array}{l}\text { Chorwacja (Slavonski } \\
\text { Brod) }\end{array}$ & 85 & 562 & $\begin{array}{l}155,25 \\
(70,25)\end{array}$ & $\begin{array}{l}114,51 \\
(29,51)\end{array}$ & Nie ma \\
\hline Macedonia (Skopje) & 93 & 1045 & $\begin{array}{c}223,63 \\
(130,63)\end{array}$ & $\begin{array}{l}147,86 \\
(54,86)\end{array}$ & Nie ma \\
\hline
\end{tabular}

Żródło: raport firmy $\mathrm{ABC}$.

Podczas analizowania tabeli 1. dobrze widać, że korzystniej zakupić towar i transportować go z Ukrainy, ale dla optymalizacji lepiej zdecydować się na przewiezienie „szerokimi” torami kolejowymi do Katowic, a następnie na załadowanie na samochody i dostarczenie na miejsce. W rezultacie czas ładunków podczas transportu wyniósł 7 dni (10-12 dni tradycyjnie), koszt transportu wyniósł $51 \mathrm{EUR} /$ tonę, a koszt towaru $\mathrm{z}$ uwzględnieniem kosztu transportu - $121 \mathrm{EUR} /$ tonę. W związku $\mathrm{z}$ tym warunki umowy zostały spełnione $\mathrm{z}$ tzw. efektem synergii.

2 Pellet - materiał opałowy ze sprasowanych w prasach (tzw. peleciarkach) pod wysokim ciśnieniem odpadów drzewnych: trocin, wiórów, zrębków; możliwe jest również wykorzystanie kory, upraw energetycznych i słomy, https://pl.wikipedia.org/wiki/Pellety\#cite_note-3 [dostęp 30.12.2018]. 


\section{Ocena efektywności tradycyjnych środków transportu w tańcuchu dostaw}

Na poziomie logistycznego zarządzania firmą zarządzanie transportem składa się z kilku podstawowych etapów:

- wyboru sposobu transportowania;

- wyboru środka transportu;

- wyboru rodzaju pojazdu;

- wyboru przewoźników i logistycznego partnera transportowego;

- optymalizacji parametrów procesu transportu.

Charakter działalności firmy wymusza następujące rodzaje transportu:

- kolejowy;

- morski;

- śródlądowy;

- drogowy;

- lotniczy.

Każdy z tych rodzajów transportu ma cechy, zalety i wady, ale łącząc je, można uzyskać optymalizację transportu i zmniejszenie kosztów dostaw.

Przy wyborze typu/typów pojazdów wymaganych dla danego przewozu, zgodnie z kryteriami koniecznego i wystarczającego stopnia sprawności, są niezbędne informacje na temat mocnych i słabych stron różnych rodzajów transportu (por. tabela 2):

Tabela 2. Wady i zalety różnych rodzajów transportu

\begin{tabular}{|c|c|c|}
\hline Rodzaj transportu & Zalety & Wady \\
\hline 1 & 2 & 3 \\
\hline Kolejowy & $\begin{array}{l}\text { - wysoka ładowność; } \\
\text { - nie zależy od warunków pogo- } \\
\text { dowych; } \\
\text { - szybka dostawa na wielkie } \\
\text { odległości; } \\
\text { - regularność ruchu; } \\
\text { - wygodne rozwiązanie procesu } \\
\text { załadunku-rozładunku; } \\
\text { - niskie stawki frachtowe. }\end{array}$ & $\begin{array}{l}\text { - niska prędkość; } \\
\text { - niewielka liczba przewoźników; } \\
\text { - kradzież i straty; } \\
\text { - niemożliwość dostarczenia } \\
\text { do klienta na miejsce (często } \\
\text { potrzebny transport samocho- } \\
\text { dowy). }\end{array}$ \\
\hline Morski & $\begin{array}{l}\text { - niskie stawki frachtowe; } \\
\text { - wysoka ładowność; } \\
\text { - wygodne rozwiązanie procesu } \\
\text { załadunku-rozładunku; }\end{array}$ & $\begin{array}{l}\text { - niska prędkość; } \\
\text { - czas dostawy; } \\
\text { - brak możliwości dostarczenia } \\
\text { do punktu konsumpcji (często } \\
\text { konieczne szyny i / lub transport } \\
\text { drogowy); }\end{array}$ \\
\hline
\end{tabular}


Tabela 2 (cd.)

\begin{tabular}{|c|c|c|}
\hline 1 & 2 & 3 \\
\hline Morski & $\begin{array}{l}\text { - regularność ruchu (muszą } \\
\text { dostosować się do harmono- } \\
\text { gramu armatorów). }\end{array}$ & $\begin{array}{l}\text { - surowe wymagania dotyczące } \\
\text { pakowania i zabezpieczania } \\
\text { tadunków; } \\
\text { - częstotliwość wysyłek; } \\
\text { - dostępność geograficzna; } \\
\text { - zależność od warunków pogodo- } \\
\text { wych i nawigacji. }\end{array}$ \\
\hline Śródlądowy & $\begin{array}{l}\text { - niskie stawki frachtowe (naj- } \\
\text { tańszy transport w transporcie } \\
\text { towarów o masie większej niż } \\
100 \text { ton na dystansie } 250 \text { km); } \\
\text { - wysoka ładowność; } \\
\text { - wygodne rozwiązanie procesu } \\
\text { załadunku-rozładunku; } \\
\text { - regularność ruchu. }\end{array}$ & $\begin{array}{l}\text { - niska prędkość; } \\
\text { - niemożliwość dostarczenia do } \\
\text { klienta na miejsce (często po- } \\
\text { trzebny transport kolejowy i/lub } \\
\text { samochodowy); } \\
\text { - częstotliwość wysyłek; } \\
\text { - zależność od warunków pogodo- } \\
\text { wych i nawigacji; } \\
\text { - dostępność geograficzna. }\end{array}$ \\
\hline Samochodowy & $\begin{array}{l}\text { - dostępność geograficzna; } \\
\text { - regularność ruchu; } \\
\text { - zdolność do dostarczania nie- } \\
\text { wielkich ilości towaru (w zależ- } \\
\text { ności od typu pojazdu); } \\
\text { - nie ma surowych wymagań } \\
\text { dotyczących opakowań. }\end{array}$ & $\begin{array}{l}\text { - } \text { koszt transportu; } \\
\text { - } \text { pilność rozładunku; } \\
\text { - możliwość splądrowania i kra- } \\
\text { dzieży pojazdów. }\end{array}$ \\
\hline Lotniczy & $\begin{array}{l}\text { - szybkość dostawy; } \\
\text { - zdolność do dostarczania na } \\
\text { obszarach oddalonych; } \\
\text { - wysokie bezpieczeństwo } \\
\text { tadunków. }\end{array}$ & $\begin{array}{l}\text { - wyższe stawki frachtowe; } \\
\text { - ograniczona wielkość partii; } \\
\text { - zależność od warunków atmos- } \\
\text { ferycznych (co prowadzi do } \\
\text { nieprzewidywalnych harmono- } \\
\text { gramów dostaw). }\end{array}$ \\
\hline
\end{tabular}

Źródto: opracowanie własne na podstawie P. Baker, P. Croucher, A. Rushton, The Handbook of Logistics \& Distribution Management, 4th ed., Kogan Page Limited, London 2010, s. 334-343.

Przy określaniu rodzaju transportu użytego do przeprowadzenia konkretnego transportu wykorzystuje się następujące czynniki, które wpływają na decyzję kierowniczą:

- czas dostawy;

- częstotliwość wysyłek;

- rzetelność zgodności z harmonogramem;

- koszt transportu;

- zdolność do wykonywania różnych ładunków;

- możliwość dostarczenia towaru w dowolne miejsce ${ }^{3}$.

3 S. Kauf, E. Płaczek, A. Sadowski, J. Szołtysek, S. Twaróg, Vademecum logistyki, Wydawnictwo Difin, Warszawa 2016, s. 145. 
Wynik wyboru środka (środków) transportu może być potwierdzony przez prowadzenie obliczeń technicznych i ekonomicznych, które są oparte na analizie kosztów, wymaganiach i umowie.

Tabela 3. Ocena różnych rodzajów transportu dla każdego z powyższych czynników

\begin{tabular}{|l|c|c|c|c|c|}
\cline { 2 - 6 } \multicolumn{1}{c|}{} & \multicolumn{5}{c|}{ Środek transportu } \\
\cline { 2 - 6 } \multicolumn{1}{c|}{} & kolejowy & drogowy & śródlądowy & morski & lotniczy \\
\hline Czas dostawy & 3 & 4 & 5 & 2 & 1 \\
\hline Częstotliwość wysyłek & 3 & 5 & 4 & 1 & 2 \\
\hline $\begin{array}{l}\text { Rzetelność zgodności } \\
\text { z harmonogramem }\end{array}$ & 2 & 3 & 4 & 1 & 5 \\
\hline $\begin{array}{l}\text { Zdolność do wykonywania } \\
\text { różnych ładunków }\end{array}$ & 3 & 1 & 2 & 4 & 5 \\
\hline $\begin{array}{l}\text { Możliwość dostarczenia } \\
\text { towaru w dowolne miejsce }\end{array}$ & 2 & 4 & 5 & 1 & 3 \\
\hline Koszt transportu & 3 & 1 & 2 & 4 & 5 \\
\hline
\end{tabular}

Źródto: ABC (wartość 1 - najlepsza, 5 - najgorsza).

Według kierownika działu logistyki wybór transportu bierze pod uwagę przede wszystkim następujące czynniki:

- rzetelność przestrzegania harmonogramu dostaw;

- czas dostawy;

- koszt transportu.

W konsekwencji wybór gałęzi transportu najczęściej uwarunkowany jest ilością przewożonego towaru i odległością do klienta.

Tabela 4. Wielkość ładunku i odległość a wybór gałęzi transportu

\begin{tabular}{|c|l|l|l|l|}
\hline \multirow{2}{*}{$\begin{array}{c}\text { Wielkość } \\
\text { tadunku }\end{array}$} & \multicolumn{4}{|c|}{ Odległość przewozu (km) } \\
\cline { 2 - 5 } & do 200 & od 200 do 1000 & od 1000 do 5000 & powyżej 5000 \\
\hline 1 & 2 & 3 & 4 & 5 \\
\hline Powyżej 100 ton & $\begin{array}{l}\text { transport } \\
\text { drogowy }\end{array}$ & $\begin{array}{l}\text { transport dro- } \\
\text { gowy, } \\
\text { transport kole- } \\
\text { jowy }\end{array}$ & $\begin{array}{l}\text { transport kole- } \\
\text { jowy, transport } \\
\text { morski }\end{array}$ & transport morski \\
\hline Od 20 do 100 ton & $\begin{array}{l}\text { transport } \\
\text { drogowy }\end{array}$ & $\begin{array}{l}\text { transport dro- } \\
\text { gowy }\end{array}$ & $\begin{array}{l}\text { transport dro- } \\
\text { gowy, transport } \\
\text { kolejowy }\end{array}$ & $\begin{array}{l}\text { transport kole- } \\
\text { jowy, transport } \\
\text { morski }\end{array}$ \\
\hline
\end{tabular}


Tabela 4 (cd.)

\begin{tabular}{|l|l|l|l|l|}
\hline \multicolumn{1}{|c|}{1} & \multicolumn{1}{|c|}{2} & \multicolumn{1}{|c|}{3} & \multicolumn{1}{c|}{4} & \multicolumn{1}{c|}{5} \\
\hline $\begin{array}{l}\text { Paletowa jed- } \\
\text { nostka tadun- } \\
\text { kowa }\end{array}$ & $\begin{array}{l}\text { transport } \\
\text { drogowy }\end{array}$ & $\begin{array}{l}\text { transport dro- } \\
\text { gowy }\end{array}$ & $\begin{array}{l}\text { transport dro- } \\
\text { gowy, transport } \\
\text { kolejowy }\end{array}$ & $\begin{array}{l}\text { transport lotni- } \\
\text { czy, transport } \\
\text { morski }\end{array}$ \\
\hline $\begin{array}{l}\text { Pojedyncza } \\
\text { paczka }\end{array}$ & $\begin{array}{l}\text { poczta, trans- } \\
\text { port drogowy }\end{array}$ & $\begin{array}{l}\text { poczta, transport } \\
\text { drogowy, trans- } \\
\text { port lotniczy }\end{array}$ & $\begin{array}{l}\text { poczta, transport } \\
\text { drogowy, trans- } \\
\text { port lotniczy }\end{array}$ & $\begin{array}{l}\text { poczta, trans- } \\
\text { port lotniczy }\end{array}$ \\
\hline
\end{tabular}

Źródło: S. Kauf, E. Paczek, A. Sadowski, J. Szołtysek, S. Twaróg, Vademecum..., s. 145; Por. J. Żak, Transport, [w:] D. Kisperska-Moroń, S. Krzyżaniak (red. nauk.), Logistyka, ILiM, Poznań 2009.

Analizując wnioski o transporcie, oprócz tych czynników należy koniecznie wziąć pod uwagę warunki kontraktu, życzenia klienta, możliwości ekonomiczne. $\mathrm{Z}$ analizy przeprowadzonej przez firmę ABC umów czynnik „koszty transportu” nie odgrywa głównej roli i ma bardziej charakter informacyjny. W rzeczywistości istnieje równowaga pomiędzy zgodnością czynników z „harmonogramu dostaw” i „czasem dostawy”. Poniższy schemat prezentuje przyjęte w spółce podejście do firmy transportowej uwzględniające różne rodzaje pojazdów.

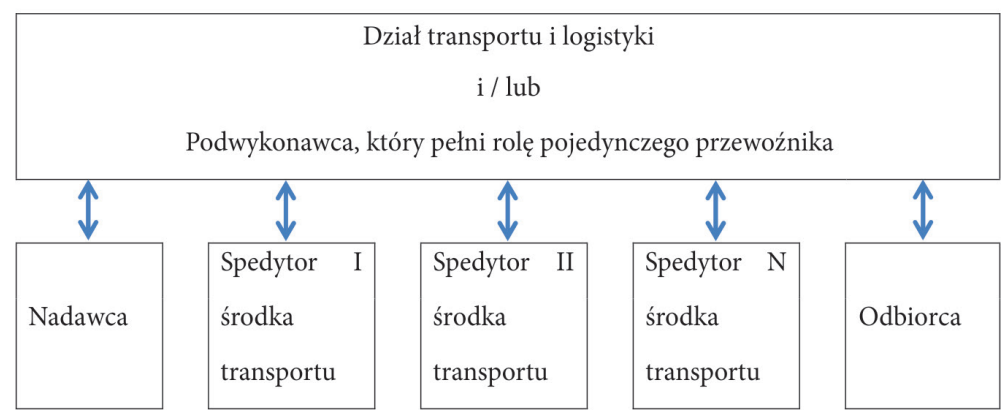

Schemat 1. Zróżnicowanie pojazdów w firmie transportowej

Źródło: opracowanie własne na podstawie danych z firmy ABC.

Jednym z kluczowych czynników w organizacji transportu jest czas dostawy. Aby dokładnie obliczyć czas przemieszczania ładunku, pomocne jest skorzystanie z następujących wzorów:

- transport kolejowy:

$$
\mathrm{T}_{\mathrm{RW}}=\mathrm{t}_{\mathrm{ST}}+\mathrm{L} / \mathrm{V}_{\mathrm{N}}+\mathrm{t}_{\mathrm{ADD}}{ }^{4}
$$

4 L. Gamkrelidze, Logistyka: teoria i praktyka, MGIU, Moskwa 2009, s. 64, https://books.google.com.ua/books?id=eJ-a10yA3kcC\&pg=PA64\&lpg=PA64\&dq=расчет\%20времени\%20 
gdzie:

$\mathrm{T}_{\mathrm{RW}}$ - czas realizacji koleją;

$\mathrm{t}_{\mathrm{ST}}$ - czas spędzony na działania przygotowawcze przed wysyłką, w godzinach;

L - odległość od początkowego do końcowego punktu transportu, w km;

$\mathrm{V}_{\mathrm{N}}$ - średnia prędkość robocza, w $\mathrm{km} / \mathrm{h}$;

$\mathrm{t}_{\mathrm{ADD}}$ - czas dodatkowych operacji w godzinach;

- transport morski:

$$
\begin{gathered}
\mathrm{T}_{\mathrm{SEA}}=\mathrm{L} / \mathrm{V}_{\mathrm{COM}} \\
\mathrm{V}_{\mathrm{COM}}=\mathrm{L} /\left(\mathrm{L} / \mathrm{V}_{\mathrm{d}}+2 \eta \mathrm{D}_{\mathrm{R}} / \mathrm{M}+\mathrm{t}_{\mathrm{ADD}}\right),
\end{gathered}
$$

gdzie:

$\mathrm{T}_{\mathrm{SEA}}$ - czas realizacji drogą morską;

L - odległość od początkowego do końcowego punktu transportu, w km;

$\mathrm{V}_{\mathrm{COM}}$ - komercyjna prędkość, mile/dzień;

$\mathrm{V}_{\mathrm{d}}$ - prędkość robocza, mile/dzień;

$\eta$ - współczynnik wykorzystania ładowności;

$\mathrm{D}_{\mathrm{R}}$ - pojemność statku, tony;

$\mathrm{M}$ - średnie dzienne tempo przeładunków w porcie, $\mathrm{t} / \mathrm{dzień}$

$\mathrm{t}_{\mathrm{ADD}}$ - czas dodatkowych operacji w godzinach;

- transport śródlądowy:

$$
\mathrm{T}_{\mathrm{RVR}}=\mathrm{T}_{\mathrm{ACC}}+\mathrm{L} / \mathrm{V}_{\mathrm{N}}+\mathrm{t}_{\mathrm{ADD}}
$$

gdzie:

$\mathrm{T}_{\mathrm{RVR}}$ - czas realizacji drogą śródlądową;

$\mathrm{T}_{\mathrm{ACC}}$ - nagromadzenie czasu, tworzenie i administracja ładunków w godzinach;

L - odległość od początkowego do końcowego punktu transportu, w km;

$\mathrm{V}_{\mathrm{N}}$ - średnia prędkość robocza, $\mathrm{km} / \mathrm{h}$;

$\mathrm{t}_{\mathrm{ADD}}$ - czas dodatkowych operacji w godzinach;

- transport samochodowy:

$$
\mathrm{T}_{\mathrm{VHC}}=\mathrm{t}_{\mathrm{ST}}+\mathrm{L} / \mathrm{V}_{\mathrm{N}}
$$

gdzie:

$\mathrm{T}_{\mathrm{VHC}}$ - czas realizacji transportem samochodowym;

$\mathrm{t}_{\mathrm{ST}}$ - czas spędzony na działania przygotowawcze przed wysyłką, w godzinach;

доставки\%20автомобильным\%20транспортом\&source=bl\&ots=bh4s5HDR7I\&sig=P47fLB mORaXiJOjeCN7Jdqrc57o\&hl=uk\&sa=X\&ved=0ahUKEwiWm4yivYnUAhXoK5oKHVB1Bnk4C hDoAQg4MAM\#v=onepage\&q=paсчет\%20времени\%20доставки\%20автомобильным\%20 транспортом\&f=false [dostęp 30.12.2018]. 
$\mathrm{L}$ - odległość od początkowego do końcowego punktu transportu, w km; $\mathrm{V}_{\mathrm{N}}$ - średnia prędkość robocza, $\mathrm{km} / \mathrm{h}$;

- transport lotniczy: obliczenia podobnie jak w transporcie drogowym.

Obliczenia czasu dostawy są wartościami absolutnymi i mogą zależeć od różnych czynników, np.: awarii pojazdu drogowego, warunków pogodowych, punktów kontroli celnej itp.

Do kosztu transportu morskiego można również włączać:

- dodatkową eksploatację lokomotyw manewrowych przy tworzeniu przesyłki;

- postój na przystani z powodu niedostępności statku do załadowania;

- zatrzymanie ładowania statku (np. brak niezbędnych dokumentów albo instrukcji dotyczących sprawnego załadunku towarów na statek);

- zajęta przystań dla statku po zakończeniu przeładunku;

- koszty konserwacji statków dla każdego wejścia i wyjścia do/z wód portowych, a także realizacji innych działań niezbędnych do zapewnienia bezpieczeństwa;

- zintegrowana obsługa stóp towarowych;

- składowanie towarów w magazynie;

- dokumenty ponownej rejestracji.

Według badań znanego amerykańskiego konsultanta w dziedzinie logistyki Herberta W. Davisa, który przez kilka lat śledził koszty logistyczne w przemyśle amerykańskim, w roku 1997 struktura kosztów logistyki wyglądała w następujący sposób:

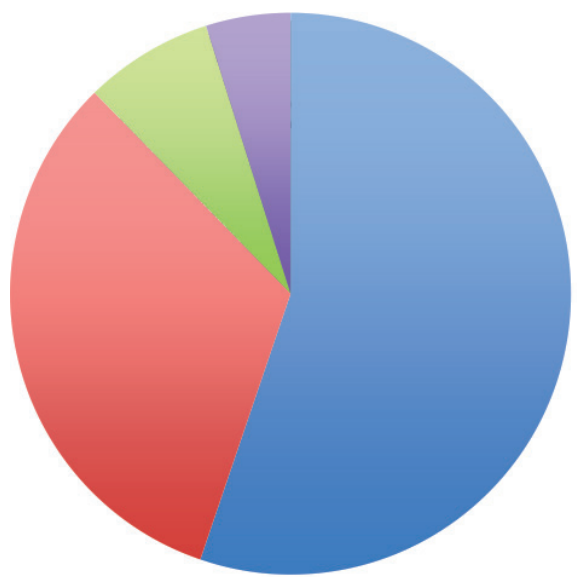

$$
\begin{aligned}
& \text { = Transport produktów } \\
& \text { gotowych } \\
& \text { = Magazynowanie } \\
& \text { Zarządzanie zamówień na } \\
& \text { usługi / dla klientów } \\
& \text { Zarządzanie dystrybucją } \\
& \text { — Koszt magazynowania } \\
& \text { zapasów }
\end{aligned}
$$

Wykres 1. Struktura kosztów logistyki w procentach

Źródło: opracowanie własne na podstawie: H. W. Davis, W. H. Drumm, Physical Distribution Cost and Service, Council of Logistics Management. Annual Conference Proceedings, Oak Brook: CLM, 1997, s. 72. 
Łączna kwota kosztów wyniosła 9,02\%.

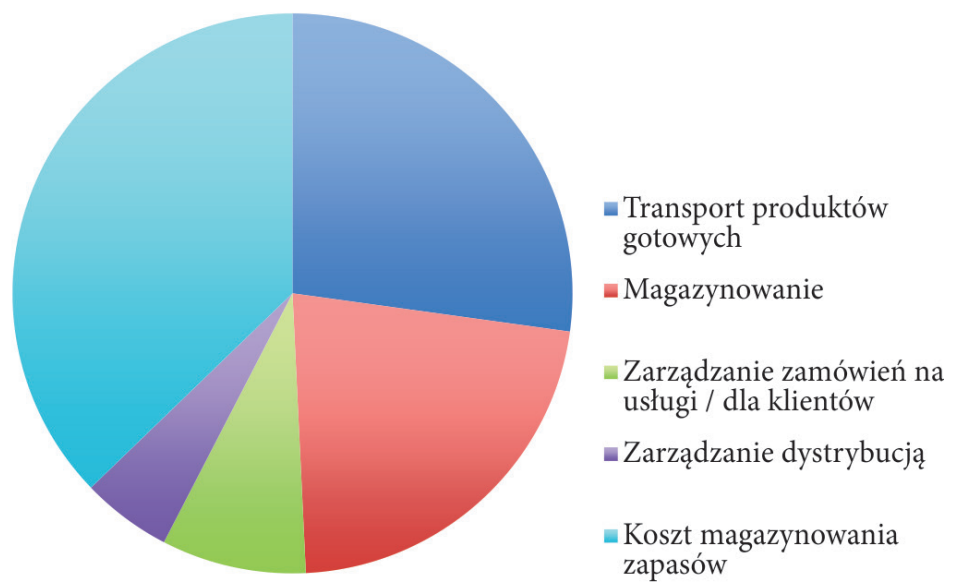

Wykres 2. Struktura kosztów logistyki w dolarach na sto funtów produktów Źródło: opracowanie własne na podstawie: ibidem, s. 72.

Całkowita kwota kosztów wynosiła 47,48 \$ za sto funtów produktów 5 .

Ale trzy lata później, w 2000 r., struktura kosztów logistyki przedstawiała się następująco:

Tabela 5. Dane przeciętnej firmy: 2000 Database

\begin{tabular}{|l|c|c|}
\hline \multicolumn{3}{|c|}{ Przeciętna firma: 2000 Database } \\
\hline \multicolumn{2}{|c|}{ koszt logistyki } \\
\hline Transport & $(\%$ sprzedaży) & \$CWT \\
\hline Magazynowanie & 3,54 & 28,42 \\
\hline Składanie zamówienia/obsługa klienta & 2,39 & 18,41 \\
\hline Administracja & 0,76 & 5,59 \\
\hline Koszt bilansowy zapasów & 0,85 & 2,84 \\
\hline Cały koszt logistyki & 2,03 & 20,18 \\
\hline
\end{tabular}

Źródto: Establish, Inc. ${ }^{6}$, [w:] Herbert W. Davis and Co.

Ta struktura kosztów jest typowa w obecnym czasie.

5 H. W. Davis, W. H. Drumm, Physical Distribution Cost and Service, Council of Logistics Management. Annual Conference Proceedings, Oak Brook: CLM, 1997, s. 72.

6 http://www.establishinc.com/ [dostęp 30.12.2018]. 
W badaniu kosztów logistyki w związku z tworzeniem strategii firmy logistycznej mamy do czynienia z problematycznymi kwestiami, które są związane z:

- niską przydatnością istniejących systemów rachunkowości i sprawozdawczości statystycznej dla wyodrębnienia poszczególnych składników kosztów logistycznych;

- brakiem informacji na temat podwykonawców;

- brakiem metodologii obliczania strat z tytułu ryzyka logistycznego;

- niewystarczającą jakością usług logistycznych, które opierają się na standardowych warunkach „usługa” i „serwis” i wskutek tego trudniej ustalić kryteria jakościowe dla tego procesu.

Poprawa jakości usług jest możliwa dzięki wprowadzeniu systemu zarządzania zgodnie z międzynarodowymi standardami - ISO 28000 - Certyfikacja systemu zarządzania bezpieczeństwem łańcucha dostaw. Głównym celem ISO 28000: 2007 jest wzmocnienie bezpieczeństwa transportu i ujednolicenie wymagań zarządzania bezpieczeństwem systemów. Skład międzynarodowych norm ISO 28000 Seria:

- ISO 28000: 2007 „Wymagania dotyczące systemów zarządzania bezpieczeństwem łańcucha dostaw";

- ISO 28001: 2007 „Systemy zarządzania bezpieczeństwem łańcucha dostaw - najlepsze praktyki wdrażania bezpieczeństwa łańcucha dostaw, oceny i plany bezpieczeństwa - wymagania i wytyczne”;

- ISO 28003: 2007 „Systemy zarządzania podażą. Wymagania sieci bezpieczeństwa dla jednostek prowadzących audyt i certyfikację systemów zarządzania bezpieczeństwem łańcucha dostaw”;

- ISO 28004: 2007 „Systemy zarządzania łańcuchem dostaw Bezpieczeństwo Przewodnik wdrażania ISO 28000".

Podstawowym dokumentem jest określona seria norm ISO 28000. Norma ISO 28000 dotyczy każdej organizacji, niezależnie od wielkości i rodzaju działalności, w ten czy inny sposób zaangażowanych w łańcuchu dostaw i chcących wdrożyć system zarządzania bezpieczeństwem, w celu zapewnienia odpowiedniego poziomu bezpieczeństwa łańcucha dostaw (lub jego części). Wśród tych organizacji mogą być:

- producenci towarów niezależnie przeprowadzający pełną lub częściową dostawę towarów;

- importerzy;

- eksporterzy;

- agenci celni;

- agenci towarowi;

- przewoźnicy (samochody, lotnicze, morskie, rzeczne);

- operatorzy terminali kontenerowych;

- lotniska, porty morskie i rzeczne, dworce;

- magazyny;

- spedytorzy;

- dystrybutorzy. 
Wdrożenie i certyfikacja systemu zarządzania bezpieczeństwem łańcucha dostaw pozwala na uzyskanie pewności co do tego, że łańcuch dostaw (lub ta część łańcucha dostaw, która kontroluje spółkę) działa w bezpiecznym środowisku. Korzyści wynikające dla firm transportowych, które korzystają z systemu zarządzania jakością wynikają z wymagań normy ISO 28000: 2007:

- zmniejszenie liczby naruszeń bezpieczeństwa, stopnia uszkodzenia wynikającego z naruszenia bezpieczeństwa, kradzieży i przemytu transportu;

- wdrożenie skutecznej kontroli i zarządzania ryzykiem w odniesieniu do zagrożeń bezpieczeństwa mających zastosowanie do rodzaju działalności;

- wzmocnienie wizerunku i reputacji niezawodnych firm partnerskich;

- optymalizacja kosztów utrzymania odpowiedniego poziomu bezpieczeństwa łańcucha dostaw (lub jego części) z powodu systematycznego wykorzystania wewnętrznych zasobów w celu zapewnienia bezpieczeństwa;

- zapewnienie utrzymania zgodności z wymogami bezpieczeństwa krajowych organizacji celnych i oprogramowania;

- bardziej efektywna komunikacja z zainteresowanymi stronami w sprawie bezpieczeństwa i świadomości, w tym działań związanych z wyborem wykonawcy.

Zdolność do tworzenia zintegrowanego systemu zarządzania ze względu na wysoki stopień harmonizacji ISO 28000, ISO 9001 i ISO 14001 pozwala na większą elastyczność w zarządzaniu procesami wewnętrznymi i skutecznie kontrolowanie i ograniczanie ich wpływu na środowisko pracy firmy.

Spółka ABC realizuje obecnie system zarządzania jakością zgodnie z normą ISO 9001 oraz ISO 22000.

\section{Wnioski}

Opierając się na analizie podstawowych danych z firmy, jest widoczne, że przewozy mogą nie tylko podnieść cenę towarów, ale także wpływają na szybkość dostarczenia. Oznacza to, że wszystko zależy od postawionych przez firmę celów i zadań transportowych.

Firmy, które połączyły organizację produkcji na zasadach logistyki, mogą sprawnie zorganizować cykl produkcyjny przedsiębiorstwa, przeprowadzić zakup surowców, wybierać dostawców, organizować sprawnie proces produkcji. Na tle znacznego wzrostu zainteresowania logistyką przedsiębiorstw i poszczególnych instytucji rządowych brakuje logistyki w życiu społeczeństwa. Tymczasem doświadczenia rozwiniętych krajów pokazują, że logistyka należy do strategicznie ważnej dziedziny.

Ważne jest, aby pamiętać, że istnieje potrzeba opracowania logistyki biznesu, strategii rozwoju spółki na okres nie krótszy niż 10-15 lat, a jej włączenie do stra- 
tegii rozwoju spółki na czas określony o długim horyzoncie. Główne bloki strategii powinny działać na zasadzie: zadań dla jednostki logistycznej w perspektywie długoterminowej; celowej pracy z dostawcami; długoterminowego programu modernizacji i rozwoju kanałów dystrybucji towaru.

\title{
Bibliografia
}

Baker P., Croucher P., Rushton A., The Handbook of Logistics \& Distribution Management, 4th ed., Kogan Page Limited, London 2010.

Coyle J. J., Bardi E. J., Langrey J. C. Jr., Zarządzanie logistyczne, PWE, Warszawa 2002.

Davis H. W., Drumm W. H., Physical Distribution Cost and Service, Council of Logistics Management. Annual Conference Proceedings, Oak Brook: CLM, 1997.

Gamkrelidze L., Logistyka: teoria i praktyka, MGIU, Moskwa 2009, https://books. google.com.ua/books?id=eJ-a10yA3kcC\&pg=PA64\&lpg=PA64\&dq=расчет\% 20времени\%20доставки\%20автомобильным\%20транспортом\&source= bl\&ots=bh4s5HDR7I\&sig=P47fLBmORaXiJOjeCN7Jdqrc57o\&hl=uk\&sa= X\&ved=0ahUKEwiWm4yivYnUAhXoK5oKHVB1Bnk4ChDoAQg4MAM\# $\mathrm{v}=$ onepage\&q=paсчет\%20времени\%20доставки\%20автомобильным\%20 транспортом\&f=false [dostęp 30.12.2018].

Kauf S., Płaczek E., Sadowski A., Szołtysek J., Twaróg S., Vademecum logistyki, Wydawnictwo Difin, Warszawa 2016.

\section{Strony internetowe}

http://www.establishinc.com/ [dostęp 30.12.2018].

https://pl.wikipedia.org/wiki/Pellety\#cite_note-3 [dostęp 30.12.2018].

\section{Place of carriage in enterprise's activity on $A B C$ company example}

\begin{abstract}
During supply chain analyze, it seen that even the best price offer reduced without transport costs. The aim of article is examine the dependence between transport costs on final prices and user interest for final products. Article presents practical connection between elements of flows logistic and team of people performing the order as a whole. Also considered topic about efficiency different means of transport, transport optimization and reduction of delivery costs. Evaluation various types of transport for various factors was carried out. Also improving the quality of services thanks to introduction of management system in accordance with international standards (including ISO 28000) was taken in attention.
\end{abstract}

Keywords: transport, logistics costs, means of transport, quality of services. 